\title{
Ämnesspråk i ett textsamtal om svetsteknik
}

\author{
Pia Visén
}

\section{Inledning}

I olika skolämnen formuleras ämneskunskaper genom olika språkliga resurser, ofta i form av texter (se exempelvis Schleppegrell 2004). Ämnets språkliga resurser bidrar då till att forma ämnesinnehållet, samtidigt som ämnesspråket formas av ämnets innehåll och sociala och kulturella kontext (jfr Bergh Nestlog 2019). Den här artikeln handlar om hur en lärare och några elever samtalar om ett ämnesbegrepp de hämtar ur en lärobokstext de läser i kursen svets grund på Industritekniska programmet (IN). Ett av skolans ämnesspråk undersöks alltså.

IN är ett yrkesinriktat gymnasieprogram, där ämnesspråkliga uttrycksformer och ämnets texter är knutna till yrkeskunskaper. Ämnesspråken inom IN konstrueras därmed med utgångspunkt i såväl yrkesmässiga och teoretiska fackspråk som mer skolanknutna undervisningsspråk. I exempelvis de styrdokument som formulerar syftet för ämnet sammanfogningsteknik, där svets grund ingår som en kurs inom ämnet, beskrivs att eleverna ska ges möjlighet att utveckla: "kunskaper om de termer och begrepp som används inom teknikområdet samt förmåga att samverka och kommunicera med människor i alla led i produktionen" (Skolverket 2011 [elektronisk resurs]). Språklig förmåga och förmåga att använda skrift, alltså att läsa, skriva och samtala om texten är alltså en central del i utbildningens mål och också en nödvändig kompetens i det moderna yrkeslivet (jfr Karlsson 2006). De kunskapskrav som gäller för ämnesspråk för exempelvis kursen svets grund inom ämnet sammanfogningsteknik formuleras enligt följande:

Eleven redogör utförligt och nyanserat för material, teknik, metoder och verktyg som använts för arbetsuppgiften samt förklarar utförligt och nyanserat hur dessa faktorer påverkat kvalitet och slutresultat. Eleven redogör utförligt och nyanserat för eventuella avvikelser från specifikationen samt den egna arbetsinsatsen. Dessutom utvärderar eleven sitt arbete och resultat med nyanserade omdömen samt ger förslag på hur arbetet kan förbättras. I redogörelser och förklaringar använder eleven med viss säkerhet korrekt fackspråk (Skolverket 2011). ${ }^{1}$

Elever ska alltså, förutom att ha kunskaper om begrepp, kunna redogöra för och förklara teknik, och ge omdömen, genom att med viss säkerhet använda korrekt fackspråk. Samtidigt som fackspråket därför behöver tränas är det också ett av de redskap som medierar ämneskunskaperna. Styrdokumentens skrivningar om att tillägna sig och lära sig använda fackspråk handlar bland annat om att elever på IN ska förstå exempelvis "hur information från tillverkningsunderlag används vid sammanfogning av material” (Skolverket 2011). För detta

\footnotetext{
1 Blockcitatet (återgivet som i originalet) visar ämnets kunskapskrav för ämnesspråklig kunskapsutveckling. Fetstil markerar betyget $\mathrm{A}$ (utförligt och nyanserat) och innefattar samtidigt betyget $\mathrm{C}$ vilket uppnås vid (utförligt). Värdeorden är alltså Skolverkets uttryck för kunskapsprogression. För att kunna nå betygsstegen över E krävs därmed sådana språkliga resurser att minst utförliga och eventuellt även nyanserade fackspråkliga resonemang och förklaringar, samt förbättringsförslag är möjliga.
} 
krävs förståelse inom ett flertal språkliga domäner både vetenskapliga och praktiska, och ett flertal uttrycksformer som exempelvis skrift, symboler, diagram och ritningar (Visén u.a.).

Styrdokumenten pekar mot att ämnesspråket i svets grund för att beskriva svetsteknikens processer är format av såväl yrkesmässigt fackspråk som tekniskt och naturvetenskapligt präglat språk. Ämnesinnehållet i svets grund, som i alla ämnen, formas av ämnesspråkets begrepp och strukturer, men också av hur dessa uttrycks (jfr Bergh Nestlog 2019). I den här studien som utgår från ett sociokulturellt perspektiv på lärande, där lärande ses som beroende av social interaktion, deltagande och insocialisering i praktiker (Säljö 2010) diskuterar jag hur några elever på IN får träna på det specifika ämnesspråket i ett textsamtal om en lärobokstext. De läser tillsammans, diskuterar lärobokstextens begrepp och relaterar dem till erfarenheter av praktiken.

En aspekt av det sociokulturella perspektivet som är central i studien är att språket ses som det viktigaste medierande redskapet i kunskapsutvecklingen (Vygotskij 2001, Wertsch 1998). Genom samtal antas därför bryggor kunna skapas från konkreta vardagliga begrepp till mer abstrakta ämnesspråkliga former (Gibbons 2006; Hajer \& Meestringa 2014; jfr Vygotskij 2001). Elever som deltar i undervisning där de får samtala om lärobokstexters ämnesinnehåll med såväl ämnesspecifika som mer vardagliga begrepp antas därför få möjlighet att utveckla kunskaper om exempelvis termer och begrepp. Vilka ämnespecifika begrepp som är undervisningens fokus och hur arbetet med dem ser ut är därmed både en språklig och en didaktisk fråga. Med ämnesspråket $\mathrm{i}$ fokus rör jag mig alltså i den här undersökningen inom vad som brukar beskrivas som den didaktiska triangeln mellan vad, hur och vem: vad, alltså det ämnesspråkliga begrepp som hämtas ur texten, hur läraren undervisar genom att språkligt bearbeta begreppet, vem, vilka möjligheter och begränsningar eleverna, genom detta ges att närma sig ett yrkesspecifikt ämnesspråk (jfr Uljens 1997; Hopmann 1997).

\section{Syfte och frågeställning}

Mot bakgrund av detta vill jag med några språkvetenskapliga verktyg analysera ett samtal om svetsteknik mellan en yrkeslärare och några elever. Jag vill därmed visa hur ämnesspråk och mer vardagligt språk samverkar när ämnesspecifika begrepp hämtas ur en lärobokstext och utforskas i ett textsamtal. Den här artikeln syftar därför till att belysa dels hur ett begrepps meningspotential utvecklas didaktiskt i en språklig kedja i ämnesundervisning i svets, dels att belysa vilka möjligheter den språkliga kedjan kan ge eleverna att utveckla förståelse för begreppet. De forskningsfrågor som ställs är följande:

- Vilka ämnesspecifika begrepp hämtas ur texten?

- Hur varieras och utvecklas begreppen i samtalet om texten?

\section{Teoretiskt ramverk}

Studiens teoretiska perspektiv grundar sig på systemisk-funktionell lingvistik (Halliday \& Matthiessen 2004, 2014), vilket innebär en funktionell språksyn. Enligt en sådan språksyn formas språket av erfarenheten av världen på samma gång som språket uttrycker erfarenheten av världen. Språket ger meningspotentialer, alltså valmöjligheter för meningsskapande. Meningen skapas samtidigt genom språkets tre metafunktioner. Den ideationella 
metafunktionen representerar innehåll och relaterar till fält, alltså ämnesområde. Den interpersonella metafunktionen representerar deltagarnas relationer och relaterar till exempelvis makt och auktoritet. Den textuella metafunktionen representerar hur en text presenteras och relaterar till kommunikationssätt (Halliday 1978; Holmberg \& Karlsson 2006). Enkelt uttryckt kan man säga att vi talar om något, till någon, på något sätt. Genom olika språkliga val, exempelvis om talaren eller skribenten använder vardagligt eller vetenskapligt språk, framträder då fältet, alltså ämnesområdet, på olika sätt. Samtidigt skapar språket olika slags relationer, exempelvis auktoritära eller jämlika. Genom språkvalen förändras också hur informationen organiseras (Halliday 1978). I den här studien är det framför allt fältet, ett ämnesspecifikt innehåll om svetsning, alltså den ideationella metafunktionen som fokuseras, men även hur informationen organiseras genom de lexikala valen, vilket faller inom den textuella metafunktionen.

Två begrepp som är viktiga i undersökningen är intertextualitet och rekontextualisering. Begreppet intertextualitet har utvecklats ur Bakhtins (1986) beskrivning av hur texter består av röster från olika källor och hur texters innehåll ekar i andra texter. En text kan vara både skriftlig, som en lärobok eller en artikel, eller muntlig, som ett samtal eller en presentation (jfr Bergh Nestlog 2019). Textinnehåll och texters röster kan då eka mellan skriftliga texter och samtal. I undervisningssituationer återanvänds och omformuleras ämnesinnehåll för didaktiska syften och rekontextualiseras (Bernstein 2000). I undervisning som utgår från lärobokstexter rekontextualiseras innehåll och språk på olika sätt, såväl inom texter, som mellan texter och mellan lästext och samtal. Då omformuleringar eller citering sker mellan texter eller mellan text och samtal innebär det intertextuella rekontextualiseringar (Linell 1998). Det vill säga en texts innehåll framträder, eller ekar, i ett samtal eller en ny text. Begreppet intertextuell rekontextualisering kan ringa in det som sker när elever och lärare samtalar om innehållet $\mathrm{i}$ lärobokstexter. Vidare kan ämnesspråket på IN ses som didaktiska rekontextualiseringar av dels tekniskt och naturvetenskapligt präglat språk, dels av det specifika industritekniska fackspråket (jfr Bernstein 2000).

\section{Om ämnesspråk och språkliga domäner}

Många forskare har intresserat sig för skolans olika språk och språkets relation till det lärande som sker (exempelvis Schleppegrell 2004; Martin \& Rose 2012; Hallesson 2015). I störst utsträckning hör de ämnesspråk som beforskats hemma på högskoleförberedande gymnasieprogram, exempelvis de naturvetenskapliga ämnesspråken (se t.ex. Kouns 2014; Ribeck 2016; Persson 2017), men även exempelvis historieämnets språk är undersökt (Olvegård 2014). Olvegård (2014) undersöker hur grammatiska deltagare i historieläroböcker kan kategoriseras lexikalt. Hon visar bland annat att en övervägande del av de grammatiska deltagarna är abstrakta/metaforiska icke-mänskliga deltagare (Olvegård 2014: 106). Dessa bildar lexikogrammatiska kedjor inom texten vilka bidrar till ämnesspråkets komplexitet (ibid.). Relationerna i kedjorna är ofta relationen helhet-delar eller relationer som skapas mellan lokala synonymier (Olvegård 2014: 148).

Ordförråd och ämnesspråk i vanligt förekommande läroböcker i matematik och natur- och samhällsorienterande ämnen för grundskolans senare år undersöktes i projektet OrdiL (Lindberg \& Kokkinakis 2007). Resultatet visade att till läromedlens komplexitet bidrog dels 
ämnesspecifika begrepp som exempelvis fotosyntes, dels ämnestypiska mer allmänna begrepp som lösning, men också lågfrekventa allmänspråkliga ord. Lindberg och Kokkinakis visar hur skolan speglar ett flertal språkliga domäner: läroboksspråk, specialiserat språk, skolspråk, vardagsspråk, vetenskapligt språk, fackspråk, akademisk vokabulär, allmänna men ämnestypiska ord och ämnesspecifika begrepp (ibid.). Författarna menar att lärare kan stötta elevers ämnesförståelse genom att uppmärksamma texters språk på fler nivåer än de ämnesspecifika begreppen. För den här undersökningen är begreppen vardagsspråk, skolspråk, fackspråk samt ämnesspråk, verktyg i diskussionen av hur elever och lärare samtalar om texten för att skapa mening och utnyttja olika meningspotentialer. Med vardagsspråk menas de vardagligare former som används även utanför skola och profession. Skolspråket innebär mer formella språkformer och kunskapsspråk som hör hemma i läroböcker och undervisning, och som även används i andra ämnen än svetsteknik. Fackspråk används i artikeln för att beskriva det professionella språk som används i svetsares yrkesutövning och i svetsprofessionens facktexter. Ämnesspråket betraktas i det här sammanhanget som den sammansmältning mellan skolspråk och fackspråk som sker i undervisningen. Inom gymnasiets yrkesprogram inkluderar därmed ämnesspråket såväl yrkesprofessionens fackspråk som vetenskapligt och tekniskt präglat språk (Visén u.a.).

Eftersom arbetslivet har förväntningar på såväl allmänna som specifika språkliga kompetenser, spelar ämnesspråk och texter en avgörande roll även på yrkesinriktade program på gymnasiet (Lindberg 2000). De ämnesspecifika texterna i yrkesämnen innehåller kunskaper som yrkeselever behöver få stöttning att tillägna sig eftersom texterna i den professionella sfären är avgörande för säkerhet och resultat och ses som verktyg i yrkespraktikerna (Lindberg 2003a, 2003b). Det finns exempel på hur yrkeslärare exempelvis i arbetet med en abstrakt facktext inom brandmannautbildning åstadkommer ett möte mellan teori och praktik, och hur det arbetet kräver sådana redskap som "[s]pråklig medvetenhet och fungerande yrkesspråk" (Göransson 2011: 13). Såväl Göransson (2011) som Lindberg (2003a, 2003b) visar behovet av språklig medvetenhet om yrkesämnesspråk. Sambandet mellan språkligt och praktiskt lärande belyses också då Asplund och Kilbrink (2018) genom samtalsanalys kombinerat med variationsteori undersöker en lärsituation i svetsundervisning.

I min avhandling (Visén 2015) undersökte jag bland annat ett antal samtal om yrkestexter och ett av resultaten var att språkliga sammanhangsmarkörer tycktes relatera till hur eleverna samtalade om texternas innehåll och den textrörlighet de uppvisade. Den lärobokstext i svetsteknik som användes $i$ ett av samtalen byggs upp multimodalt med såväl verbala som visuella inslag och syftar till att utgöra underlag för ett görande, i det här fallet svetsning. Lärobokstexten undersöktes språkvetenskapligt av Danielsson och Selander (2014). De fann att texten trots sitt mer praktiska syfte, i hög grad är teoretisk, och att innehållet samtidigt är "en förutsättning för hög kvalitet på kommande slutprodukter" (Danielsson \& Selander 2014: 140). Mina avhandlingsresultat och Danielsson och Selanders undersökning av texten väckte mitt intresse för vilka språkliga mönster som uppstår då textens och yrkespraktikens ämnesspecifika språkdomäner möter vardagliga språkdomäner i textsamtalet. En sådan undersökning kan ge ny kunskap ur två perspektiv. Det ena perspektivet är att den tidigare forskning om ämnesspråk som finns framförallt rör skolans teoretiska ämnen. Undersökningen kan därför fylla en forskningslucka genom att ge en förståelse av yrkesämnesspråk. Det andra är att undersökningen genom att följa de språkliga mönstren kan visa huruvida samtalet kan 
skapa en brygga mellan en lärobokstexts teoretiska karaktär och språk och en hantverkspraktik. Detta kan vara viktig kunskap bland annat i utbildningen av yrkeslärare.

\section{Material och metod}

Empirin hämtas alltså ur ett större material (Visén 2015) och består dels av en transkriberad videoupptagning av ett 40 minuter långt textsamtal mellan en lärare och en grupp elever på industritekniska programmet på gymnasiet, dels av en lärobokstext i svetsteknik som samtalet utgick ifrån (Henriksson \& Hällman 2009: 95-99). Etiska hänsyn har tagits med utgångspunkt i Vetenskapsrådets codex (2002). Deltagande lärare och elever, samt vårdnadshavare till omyndiga elever gav skriftligt samtycke efter att ha informerats både muntligt och skriftligt om forskningsprojektets syfte och genomförande. De garanterades konfidentialitet och rätt att avbryta deltagande, samt att materialet enbart nyttjas för forskning.

\section{Samtalet}

Samtalet inleds med att läraren kort introducerar innehållet i dagens lektion: "Vi ska läsa ett avsnitt i boken nu som heter Spänningar och deformationer. Termisk cykel vid svetsning". Lästexten hämtas ur läroboken Bågsvetsning (Henriksson \& Hällman 2009). Läraren beskriver för eleverna att de ska läsa lite i taget och samtala om det de läst så att de förstår. Läraren introducerar kortfattat ett stycke i taget och ber eleverna att läsa. Eleverna läser stycket individuellt och läraren läser sedan något begrepp ur textavsnittet högt, upprepar det och samtalar sedan med eleverna om det begreppet.

\section{Lärobokstexten}

Textavsnittet klassen arbetar med handlar om hur värme vid svetsprocessen kan påverka svetsmaterial. Det aktuella kapitlet beskriver spänningar och deformationer under den termiska cykeln vid svetsning. Texten innehåller verbaltext, skisser och bilder. Textens olika delar samspelar och illustrationerna konkretiserar eller kompletterar verbaltexten (Danielsson \& Selander 2014: 138). Figur 1 visar ett exempel på hur texten är konstruerad med både verbala och visuella inslag. 


\begin{abstract}
I vissa fall räcker det inte med att svetsförbandet får svalna i långsammare takt utan en värmebehandling måste utföras innan svetsförbandet får önskvärda egenskaper. Exempel på värmebehandlingar efter svetsning är normalisering och avspänningsglödgning.
\end{abstract}

I materiallära för svetsare beskrivs svetsmetallurgin $\mathrm{i}$ detalj.

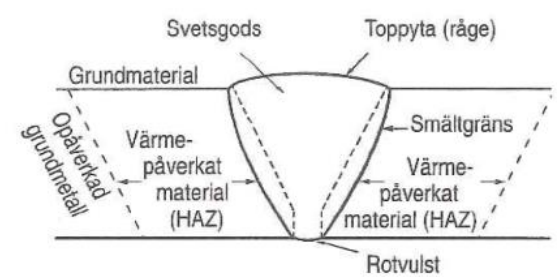

\section{Ufvidgning odh Ikrympning}

De flesta metalliska material ändrar volym när temperaturen ändras. Vid upphettning ökar volymen och vid avkylning minskar den. En stång av stål blir $9 \mathrm{~mm}$ längre per meter när den värms så att temperaturen ökar $600^{\circ} \mathrm{C}$. När den svalnar àtergår den till sin ursprungliga längd.

När man svetsar blir materialet uppvärmt till en temperatur som medför en betydande längdökning. När svetsen kallnar krymper materialet. Krympningen sker både tvärs svetsen (tvärkrympning) och längs svetsen (längskrympning). Även i svetsens tjockleksriktning sker en viss krympning.

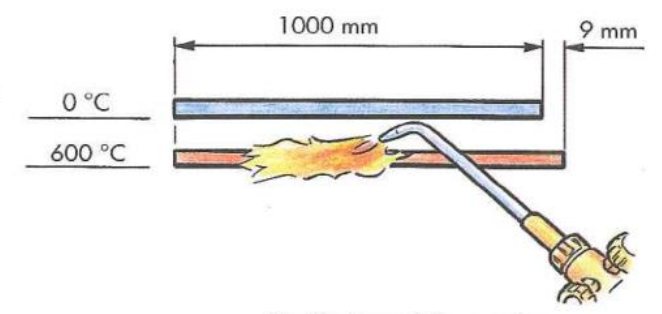

Utvidgning och krympning

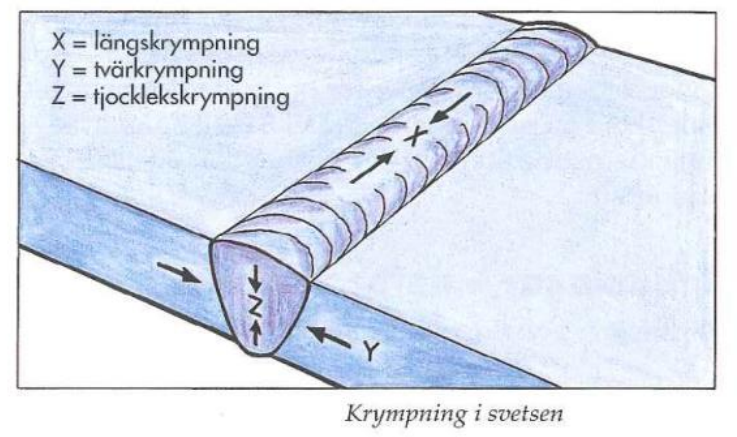

Figur 1. Utdrag ur lästexten om bågsvetsning (Henriksson \& Hällman 2009: 96, med förlagets godkännande).

Läroboken innehåller ett flertal ämnesspecifika fackuttryck som exempelvis "vinkeldeformation", "svetsgods", "toppyta" och "tvärkrympning". Danielsson och Selander (2014) visar att termerna är såväl ämnesspecifika, exempelvis "rotvulst" och "smältgräns", som mer allmänna, exempelvis "grundmaterial". Språket i läroboken kan associeras med naturvetenskapligt språkbruk, och andelen ämnesspecifika termer och grammatiska metaforer ${ }^{2}$ är hög. Grammatiska metaforer komprimerar texten och omvandlar skeenden till företeelser, som exempelvis "avspänningsglödgning" som annars skulle kräva en längre förklaring av hur någon hettar upp metall så att den glöder för att avlägsna spänningar i metallen. Textens bildspråkliga metaforanvändning hör hemma inom tekniska eller naturvetenskapliga språkliga domäner. Ämnesspecifika begrepp som exempelvis "svetsmetallurgi", förklaras inte i texten. Begreppet "deformation" jämförs dock med den metaforiska användningen av det mer allmänspråkliga "slår sig" (jfr Danielsson \& Selander 2014). Fokus i det undersökta samtalet är uttrycket "Värmepåverkat material (HAZ)". HAZ är en engelsk akronym som står för termen Heat Affected Zone, vilket inte förklaras i lärobokstexten. I svetspraktiken används på detta sätt ibland engelska uttryck för vissa begrepp.

2 En grammatisk metafor innebär att uttrycka något i en grammatisk form som skiljer sig mot den vanligare grammatiska formen. Grammatiska metaforer förekommer ofta i mer vetenskapligt präglad text, eftersom det kan komprimera informationen. Det kan exempelvis innebära att en process nominaliseras, alltså att verb görs om till sustantiv, exempelvis: att värma upp $\rightarrow$ uppvärmning. Det kan också innebära att en process adjektiviseras, alltså att ett verb görs om till adjektiv, exempelvis: påverkade med värme $\rightarrow$ värmepåverkat. 


\section{Analysverktyg}

I det här avsnittet presenteras de analysverktyg som används. Analysverktygen kan visa hur ämnesspråk framträder i ett textsamtal genom att följa hur begrepp som hämtas ur en lärobokstext på olika sätt rekontextualiseras genom att repeteras och omvandlas i textsamtalet. Att materialet har en intertextuell karaktär som innebär att ett samspel mellan lärobokstext och samtal får till följd att analysen för att fånga innehållet måste vara pragmatisk och semantiskt tolkande, samtidigt som den har en klassificerande ansats. För att uppnå detta är den styrande principen språkets funktion i samtalet. En lexikal enhet kan därför ibland utgöras av ettordsbegrepp eller ettordsfraser och ibland flerordsbegrepp eller flerordsfraser och hela satser. Det gör det möjligt att fånga innebörder och undervisningsinnehåll och inte isolera enheter som hänger samman språkligt-semantiskt (jfr Eggins 2004). Exempelvis analyseras frasen "slår sig" som en lexikal enhet.

\section{Lexikala relationer}

Innehållsord, som exempelvis svetsa, utgör kärnan i en beskrivning av ett ämnesområde (Halliday \& Matthiessen 2014). De här orden skiljer sig därför från formord, som exempelvis att. Innehållsorden i en text relaterar till varandra och skapar logik och mening genom sammanhangsrelationer (Eggins 2004). Att undersöka innehållsord ur ett ämnesspråkligt perspektiv kan därför visa hur logik upprättas och meningspotentialer utnyttjas för att skapa ett ämnesinnehåll. Ord eller lexikala enheter hänger ihop på olika sätt, exempelvis bildar relationerna mellan orden yrke-svetsare-professionell betydelsebärande sammanhang genom lexikala relationer. Lexikala relationer är av två huvudtyper. Den ena huvudtypen innebär taxonomiska relationer som upprättar klassificerande samband, exempelvis mellan del och helhet, kropp - arm. Den andra huvudtypen innebär förväntade relationer, det vill säga att lexikala relationer upprättas genom ett förväntat (men inte taxonomiskt) samband (Eggins, 2004). Exempelvis är fot - sko en förväntad relation. Ett annat exempel på en förväntad relation är läsa - bok, som relaterar verb och nominal till varandra. De lexikala enheterna läsa - sko har däremot ingen relation vare sig som taxonomisk eller förväntad relation.

De taxonomiska relationerna består av:

- repetitioner

- synonymer, synonyma uttryck

- antonymer, alltså motsatser eller kontraster

- hypo- och hyperonymer,

- alltså under- eller överordnade begrepp

- meronymer, alltså del-helhetsrelationer svets-svets verktyg-redskap varm-kall verktyg-hammare hammare-skaft

De förväntade relationerna består av:

- lexikala enheter som kan förväntas ha innehållsligt samband - exempelvis mellan nominal och verb, bok-läser

- eller mellan ord som kopplas samman semantiskt, exempelvis blixt-åska

En lexikal enhet kan ibland fungera i fler än en relation (Halliday \& Matthiessen 2014: 643 ff). Exempelvis kan ordet "värmer" samtidigt som det är en förväntad relation till "värmepåverkat 
material" fungera som exempelvis hyponym till "värmepåverkat". Ett ord kan alltså ha två eller flera funktioner samtidigt och lexikalt knyta samman olika ord. I samtalet i den här studien fungerar exempelvis ordet "plåtar" samtidigt som en repetition i en beskrivning av innehållet i en bild, och som synonym till det verbalspråkliga "material".

Lärobokstexten i undersökningen är multimodal. Texters innehåll är ofta multimodalt konstruerat av såväl verbala som visuella representationer för att skapa mening (Unsworth 2001). Analysen av textsamtalet inkluderar därför referenser till såväl textens verbala som visuella inslag. För att begränsa begreppsanvändningen används analysbegreppen för lexikala relationer på liknande sätt oberoende av om det som läses är verbalspråkligt eller om läsandet utgår från andra multimodala representationer. Jag tolkar på så vis ett begrepp som används för att återge innehållet i en bild eller skiss som en repetition. Jag tolkar en liknelse till bilden som ett synonymt uttryck, ett omnämnande av en undergrupp till bildens innehåll som en underordnad, hyponym, relation. Ett benämnande av en del av innehållet i bilden, exempelvis "skaft" om bilden föreställer en hammare, tolkas som en meronym relation. Ett uttryck som för in underförstådd information eller ett förklarande samband som inte förvånar tolkas som en förväntad relation. Ett exempel är då "punktar ihop" används för att samtala om en bild som föreställer ett svetsvärmemönster. Det innebär att ett nominal, alltså ett substantiv, som illustreras beskrivs med en process, alltså ett verb. På detta sätt fångas hur läsarna språkligt konstruerar lexikala samband med texten som multimodal helhet.

\section{Lexikala länkar och kedjor}

De språkliga val som görs skapar mönster bland annat genom hur innehållsord genom de olika lexikala relationerna länkar i varandra och bildar kedjor som utvidgar, utvecklar och förhandlar mening (Halliday \& Matthiessen 2014). En lexikal kedja kan expanderas på tre sätt, genom bearbetning, utsträckning och förstärkning. Repetitioner och synonyma uttryck fungerar som bearbetning, hyperonyma samt meronyma uttryck som utsträckning, och förväntade relationer fungerar som förstärkning av den ursprungliga lexikala enheten (Halliday \& Matthiessen 2014: 644-649). Såväl den lexikala kedjans längd som variation har betydelse för hur mening konstrueras (Halliday 2014: 607). Sammanhang och mening kan också skapas genom att olika kedjor interagerar (ibid.).

I artikelns analys av hur lexikala enheter länkar i varandra, alltså hur lexikala kedjor bildas genom lexikala relationer mellan språkliga uttryck i text och textsamtal visas hur dessa kedjor expanderar ämnesinnehållet (Halliday \& Matthiessen 2014; Halliday \& Hasan 1976; Eggins 2004; Visén 2015; Hallesson \& Visén 2016).

\section{Analys av begrepp som hämtades ur lärobokstexten}

I det här avsnittet beskrivs resultatet av analysen av vilka ord och fraser som hämtas direkt ur lärobokstexten klassen läser och som lyfts in i samtalet som citat eller beskrivning av en bild. Dessa är:

- "värmepåverkat material (HAZ)"

- "termisk cykel"

- "deformationer" 
- "utvidgning"

- "krympning"

- "slår sig"

- "arbetsstycken"

- "varmriktning"

- [ur en bild] "punktar ihop"

- [ur en bild] "kälfog"

- [ur en bild] "kil"

- [ur en bild] "pil"

- "arbetsstycke"

- "chockvärmebehandling"

Begreppen hämtas ur texten genom att eleverna först har läst de stycken (ett stycke i taget) där begreppen återfinns, och läraren sedan läser dessa högt och repeterar de lexikala enheter som förs in i samtalet. Samtalet utgår från begreppet "värmepåverkat material (HAZ)" vilket hämtas ur en principskiss i texten (se figur x). Begreppet används för det område av svetsmaterialet som i arbetet på olika sätt påverkas av värmen i svetslågan.

Det är främst nominal som "deformationer" och "arbetsstycke", samt nominaliseringar som exempelvis "varmriktning" och "chockvärmebehandling" som hämtas ur texten. Textens bilder beskrivs exempelvis med begrepp som kil eller pil, men även genom processen "punktar ihop" vilket refererar till en bild på en pågående svetsprocess.

\section{Hur de ämnesspecifika begreppen expanderas}

I följande avsnitt beskrivs resultatet av analysen av lexikala relationer och hur begreppen ur lärobokstexten utvecklas och länkar i andra ord i samtalet. Exemplet nedan är ett kort utdrag från början av samtalet. De lexikala enheterna som analyseras visas understrukna (då citat läses ur texten markeras det även med citattecken). Analys av lexikala relationer och typ av expansion anges i hakparenteser:

1. Lärare: Om vi börjar med det här: "Värmepåverkat material. HAZ". [repetition: bearbetning] Axel vad är det för nånting?.

2. Elev: ingen aning

3. Lärare: Vet du vad de där tre bokstäverna står för? [synonym: bearbetning]

4. Elev: Värme nånting... [synonym: bearbetning]

5. Lärare: mm På engelska.

6. Elev: Hot. [synonym: bearbetning]

7. Lärare : Ja Heat. Affected. Zone. [repetition: bearbetning]

8. Elev: Zone? [repetition: bearbetning]

9. Lärare: Zon. [repetition: bearbetning] Om ni tittar på den där lilla svartvita bilden där, alltså värmepåverkat material [repetition-bearbetning], när ni svetsar [förväntad relation: förstärkning], så tillför ni ju [förväntad relation: förstärkning], otroligt mycket värme [synonym: bearbetning] ju eller hur?.

10. Elev: juu 
11. Lärare: Då får man ju, alltså vid sidan av svetsen [synonym: bearbetning], ett område [synonym: bearbetning] som blir värmepåverkat [förväntad relation: förstärkning] och vad händer med plåten [synonym: bearbetning] där? I den där zonen [repetition: bearbetning]?

12. Elev: Det krymper [förväntad relation: förstärkning]

13. Lärare: Ja dels krymper den ju... [förväntad relation: förstärkning]

14. Elev: Det bågnar! [förväntad relation: förstärkning]

Exemplet visar bearbetning och förstärkning av textinnehållet genom repetitioner, synonyma och förväntade relationer. Läraren läser ur texten (1), i samtal med eleverna reder hen ut vad akronymen står för (3-9), upprepar begreppet och bjuder in elevernas egen erfarenhet (9), bearbetar vad som händer (11) och eleverna bidrar med erfarenheter $(12,14)$.

I samtalet framträder ett språkligt mönster när läraren och eleverna utforskar textens innehåll och språkligt expanderar ett ämnesspecifikt begrepp. Lärobokstextens språk förs in i samtalet genom repetitioner. Sedan expanderas textens språk i synonyma uttryck, över- och underordnade begrepp och förväntade relationer, för att $i$ slutet av samtalet summeras i repetition av ämnesspecifika språkliga uttryck ur texten. Detta bildar en lexikal kedja. Analysen visar hur kedjan innefattar citat ur texten och hur dessa utvecklas i olika uttryck och fraser.

\section{Den långa lexikala kedjan}

Den långa lexikala kedjan utgår alltså från textcitatet "Värmepåverkat material (HAZ)" och innefattar all expansion av det textinnehåll klassen samtalar om. Kedjan består av 194 lexikala enheter, alltså fraser, som håller samman ämnesinnehållet i samtalet. I tabell 1 återfinns några exempel i kronologisk ordning ur den långa lexikala kedjan:

Tabell 1. Exempel på lexikala relationer ur den långa kedjan.

\begin{tabular}{|l|l|l|l|}
\hline Lärobokscitat & & Lexikal relation & Talare \\
\hline Värmepåverkat material (HAZ) & & Repetition & Lärare \\
\hline & Värme nånting & Synonym & Elev \\
\hline & Plåten & Synonym & Lärare \\
\hline & Alldeles bredvid svetsen & Synonym & Lärare \\
\hline & Inte i svetsen & Antonym & Lärare \\
\hline & Tillför värme & Förväntad relation & Lärare \\
\hline & Blir värmepåverkat & Förväntad relation & Lärare \\
\hline & Krymper & Förväntad relation & Elev \\
\hline & Krymper & Förväntad relation & Lärare \\
\hline & Bågnar & Förväntad relation & Elev \\
\hline Deformationer & & Repetition & Lärare \\
\hline Materialet slår sig & & Repetition & Lärare \\
\hline & Plattjärn & Hyponym & Lärare \\
\hline & Inte ska slå sig & Antonym & Lärare \\
\hline Termisk cykel & & Repetition & Lärare \\
\hline
\end{tabular}

Begreppet "värmepåverkat material (HAZ)" bearbetas dels genom att repeteras flera gånger, dels genom synonyma relationer, exempelvis likställs "materialet" med "plåten", eller "HAZ" med "alldeles bredvid svetsen". Begreppet utsträcks dels genom antonyma uttryck, exempelvis pekar läraren ut är "HAZ [...] inte i svetsen", dels genom hyponyma relationer, till exempel 
"plattjärn" och "balkbitar", vilka är underordnade "material". Begreppet förstärks genom förväntade relationer som för in processer, det vill säga verb (jfr Halliday \& Matthiessen 2014: 643-649). Exempelvis säger läraren "så tillför ni otroligt mycket värme" och "ett område som blir värmepåverkat" och frågar eleverna vad som händer då och får till svar att det "krymper" och "bågnar" men även att det "blir längre".

Kedjan går in i och ut ur den lästa texten, och nya fraser ur texten fogas in och bygger på och utvecklar det begrepp samtalet utgick ifrån. Det skapar en lång intertextuell lexikal kedja som håller samman och bygger lektionens undervisningsinnehåll språkligt genom ord som lexikalt bearbetar, sträcker ut och förstärker ursprungsuttrycket. I samtalet konstruerar och förhandlar därmed lärare och elever om läroboksuttryckets meningspotentialer genom de olika synonyma uttryckssätten, hyponymerna och de förväntade relationerna. Den långa kedjan utvecklar alltså begreppet ur flera innehållsliga perspektiv och genom varierade lexikala relationer.

Analysen av den långa intertextuella lexikala kedjans utveckling visar att när samtalet inleds repeteras ett ämnesspråkligt uttryck ur lärobokstexten "värmepåverkat material", som på det viset bearbetas, sedan dominerar mer vardagliga uttryckssätt. Begreppet ur läroboken repeteras med tillägg av en process "blir värmepåverkat". Läraren upprättar alltså förväntade relationer genom processer och vardagligare uttryck som expanderar kedjan genom förstärkning. Då samtalet går mot sitt slut introducerar läraren allt fler repetitioner av abstrakta ämnesspråkliga begrepp som exempelvis "deformationer", och mer vardagliga uttryck som exempelvis "bågnar" minskar i antal. Läroboksspråket tycks alltså rama in det utforskande av begreppens innehåll som sker.

Genom de förväntade relationer som kedjan innehåller knyts begreppet "värmepåverkat material (HAZ)" till processer som exempelvis "tillför otroligt mycket värme". Det innebär att eleverna kan föras in som deltagare "när ni svetsar tillför ni”", och elevernas praktikerfarenheter kan utnyttjas, vilket även kan bidra till att sänka abstraktionsgraden. Det kan tänkas att detta sätt att organisera innehållet i samtalet kan befästa förståelse för de ämnesspråkliga uttrycken genom att de har rekontextualiserats av mer vardagliga uttryckssätt utan att lämna lärobokens ämnesspråk. Då abstrakta och mer vetenskapliga begrepp utvecklas i samspel med vardagliga begrepp på det sätt som sker i samtalet kan ämnesspråklig begreppsutveckling stöttas (jfr Vygotskij 2001).

\section{Delkedjorna}

Innebörden i begreppet "värmepåverkat material" innefattar tre fenomen: värme, påverkat (med värme) och material, och i akronymen HAZ innefattas även innebörden område (snarare än material) genom det engelska zone. I analysen beskrivs och exemplifieras därför även lexikala relationer i fyra interagerande delkedjor: en kedja som följer delbegreppet värme, en som följer delbegreppet påverkat, en som följer delbegreppet material och en som följer delbegreppet zone/område. Engelska och svenska får ses som utbytbara i sammanhanget. Delkedjorna korsar varandra men skapar också länkar genom samma enheter. Förståelsen av hur lärobokstexten expanderas, och hur de intertextuella rekontexualiseringarna sker framträder ytterligare om begreppet delas upp i de delkedjor de bildar var och en för sig. 


\section{Delkedja 1: Värme}

Ett antal av fraserna i samtalet bildar länkar med värme och vi kan urskilja en kedja av lexikala enheter:

Värme: värme nånting - hot - heat - värme - värme - kallning - värmezonen - värme - kallning - termisk - termisk - termisk energi - temperaturen - temperatur - för varmt - värme - värms - " $600^{\circ}$ " - svalnar - värmer - 600 grader - kallnar - värme - kyla varmt - kallt - minus 30 - plus 30 - värme - varmare - värmen - värmen - värme värmen - värmen - värmen - värmen - varmriktning - värmer - värmer - värmer slutar värma - värmt - värmer - värmer - för varmt - varmrikta - termisk cykel termisk energi - termisk energi - temperaturen - termisk cykel - termisk cykel termisk cykel - förvärma - avglödga

I den lexikala delkedjan som utgår från begreppet värme repeteras begreppet ett relativt stort antal gånger, men även ett antal synonyma uttryck används, exempelvis "heat", "termisk", samt några antonymer: "svalnar", "kallt", "kyla". Detta expanderar uttrycket genom bearbetningar. Ett antal uttryck för över- och underordning sträcker ut begreppets innebörd, exempelvis "termisk energi", "600 grader", "temperaturen". Den lexikala kedjan innehåller också ett antal förväntade relationer som förstärker begreppets innebörd, exempelvis "värmer", "varmrikta", "förvärma" där begreppet knyts till processer.

\section{Delkedja 2: Påverkat}

Ett antal fraser i samtalet länkar också ihop med påverkat och vi kan urskilja ytterligare en kedja av lexikala enheter:

Värmepåverkat: tillför otroligt mycket - blir värmepåverkat - vad händer - krymper krymper - bågnar - går sönder - blir skört - påverkas - påverkar - "deformationer" deformationer - hur brukar det se ut när ni har svetsat - så här ser de ut - varför ser de ut så här - lägger en svets - lägger på en massa värme - drar - utåt - drar upp sig dragning - drar upp sig - sträckning - blir bitarna - ser ut så - "utvidgning och krympning" - utvidgning och krympning - "blir 9 mm längre per meter" - "när den svalnar återgår den till sin ursprungliga längd" - värmer - 9 mm längre - kortare tillbaka - tillbaka till sin ursprungslängd - $9 \mathrm{~mm}$ - spricker - svetsa - svetsar - drar ihop sig - skrynklar - skrynkliga - punktar, inte kör för varmt - jätteskrynkligt svetsar - punktar ihop - punktar ihop - svetsar - motverka deformation - "materialet slår sig" - slår sig - slagit sig - punktar upp - punkt - punkter - drar upp sig - punkt rätar upp sig - punktar - punktar - böjer den sig - punkt - böjer upp - spricker - hur mycket han slår sig - svetsa - böjde inte upp sig tillräckligt - svetsar - böjer den upp sig och blir alldeles rak - varmriktning - bågnat - värmer - värmer - kommer att gå upp - sen går den ner igen - värmer häruppe - slår sig ännu mer - går ner - vad är det vi gör - värmer - vidgar sig - blir större - vad händer sen när vi slutar värma - krymper - värmt - varför gör man som man gör på bilden där när man värmer - få ut han värmer - ska den ju dra - krokigt - räta ut sig - riktat - deformation - hur undviker man deformationer vid svetsning - inte ska slå sig - dra sig - varmrikta deformationer - svetsar - slår sig - påverkas - chockvärmebehandling - förvärma avglödga - undvika spänningar och deformationer

I den lexikala delkedjan som utgår från begreppet påverkat ser vi hur begreppet bearbetas i ett par repetitioner, påverkas, påverkat, men också exempelvis i det synonyma uttrycket "tillför otroligt mycket värme". Kedjan innehåller också överordnade begrepp som exempelvis "lägger en svets", vilket sträcker ut begreppet. Begreppet expanderas dock främst i förväntade 
relationer: "krymper", "krokigt", "vidgar sig", "förvärma", "avglödga", ord som skapar semantisk logik och inte förvånar utan förstärker innehållet i begreppet. I den här delkedjan inkluderas vissa frågesatser eftersom dessa är starkt semantiskt och pragmatiskt integrerade, det vill säga har stor betydelse för hur samtalet skapar lexikalt och innehållsligt sammanhang kring begreppet.

\section{Delkedja 3: Material}

Några av samtalets lexikala enheter bildar länkar med begreppet material och vi kan urskilja en lexikal delkedja:

$$
\begin{aligned}
& \text { Material: material - plåten - materialet - plåtbitar - bitarna - stång av stål - en stång } \\
& \text { av stål - material - balkbitar - rör - balkbitarna - plătar - rör - plåtarna - plåtar - } \\
& \text { plåtbitarna - plattjärn - plattjärnet - plåten - v-fog - v-fog - bitarna - bitarna - biten - } \\
& \text { kälfog - biten - materialet - arbetsstyckena - biten - plåt - materialet - plåten - } \\
& \text { materialet - plåt - kälfog - kälfog - kälfogen - "arbetsstycket" - arbetsstycket - } \\
& \text { svetsmaterial - pryl }
\end{aligned}
$$

I den lexikala delkedjan som utgår från material bearbetas begreppet i ett par repetitioner och ett uttryck som i den här kontexten fungerar synonymt, "plåten". Här ser vi också i tillägg till det ett större antal underordnade enheter exempelvis "stång av stål", "balkbitar", "plåtbitar", "plattjärn", "arbetsstyckena", vilket expanderar kedjan genom utsträckning.

\section{Delkedja 4: Zone (område)}

Den fjärde lexikala delkedja som kan urskiljas länkar ihop fraser som utgår från Z i akronymen HAZ och fångar innebörden zone/område:

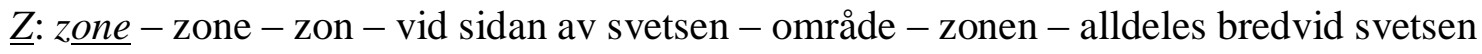
- bredvid - bredvid - inte i svetsen - värmezonen - precis vid sidan - ovansidan häruppe - ovansidan här på plåten - kil - pil - yta - kil

I den lexikala delkedjan som utgår från innebörden i zonelområde som finns inbäddat i akronymen HAZ bearbetas innebörden i repetitioner och synonyma uttryck som "vid sidan av svetsen", "alldeles bredvid svetsen", "ovansidan här på plåten", och en antonym relation "inte i svetsen". "Kil", och "pil" är underordnade begrepp som sträcker ut innebörden i begreppet genom att beskriva hur området kan utformas pil- eller kilformat.

\section{Kedjornas länkar}

Analysen av de olika kedjorna visar att de olika delkedjorna skiljer sig åt. Bland annat är delkedjan som kan knytas till "påverkat" avsevärt längre och har fler länkande lexikala enheter än de övriga. Halliday och Matthiessen menar att den lexikala kedjans längd på ett distinkt sätt bidrar till den mening som konstrueras och tolkas (2014: 607-608). Länkarna som utgår från "påverkat" kan alltså i hög grad antas bidra till det meningsskapande som sker i samtalet. Kedjans länkar består av många processer, det vill säga verb. Att den intertextuella kedjan som utgår från "påverkat" dominerar kan därmed bidra till att fokus i läsandet läggs på görandet. Det som främst utforskas och förhandlas i relation till lärobokstexten är svetsarens agerande och konsekvenserna av det, och det blir därmed fokus i undervisningsinnehållet och ämnesinnehållet även språkligt. Lärobokstexten klassen har läst är nominaltung, och det är 
främst nominal eller nominaliseringar som hämtas ur lärobokstexten, men i samtalet läggs förklarande processer till. Läraren säger exempelvis "...och så står det, 'termisk cykel vid svetsning är ett slags chockvärmebehandling [nominalisering]', ett sätt att undvika det då är att förvärma [process], kan avglödga (sic!) [process].” Det yrkesspecifika ämnesspråket knyts på så sätt i undervisningen till processer, ett görande. Språkligt betonas att det är hur svetsaren påverkar materialet med värme som styr hur deformationer uppstår och förhindras och därmed hur slutprodukten blir.

En undersökning av delkedjornas samspel visar alltså att kedjornas länkar hakar i varandra genom att nominal och ämnesspecifika nominaliseringar hakas i processer som kan knytas till elevernas tidigare erfarenheter och kunskaper ur undervisning och praktik.

\section{Arbetet med ämnesspråk i undervisning på yrkesprogram}

I det här avsnittet förs en diskussion om hur ämnesspråket, och därmed ämneskunskapen, utvecklas i samtalet genom hur det språk som hämtas ur lärobokstexten utvidgas, utvecklas och förhandlas språkligt. Av resultatet framkommer att det i textsamtalet sker en utveckling mot ett mer abstrakt ämnesspråk under lektionens gång. Den ämnesspråkliga utvecklingen uttrycks dock enbart av läraren och inte av eleverna som deltar i samtalet. Eleverna expanderar visserligen det begrepp man arbetar med på ett varierat sätt genom att de repeterar, alltså bearbetar, synonymiserar, alltså sträcker ut, och ger förväntade relationer, alltså förstärker. Men eleverna rör sig språkligt främst i en vardaglig domän. Då läraren mot slutet av samtalet sammanfattar med hjälp av lärobokens mer ämnesspecifika språk deltar de inte muntligt utan lyssnar enbart. Endast ett fåtal av elevernas språkliga uttryck kan sägas vara ämnesspecifika. Ett uttryck som hämtas ur läroboken, och som läraren lyfter fram som ett ämnesspråkligt fackuttryck, används dock vid ett antal tillfällen även av eleverna. Det är uttrycket "materialet slår sig". Ett annat fackuttryck som används av elever är "punktar ihop". Detta uttryck används för att beskriva innehållet i en bild men finns inte i verbaltext. I övrigt är elevernas språk mer vardagligt. De abstrakta och naturvetenskapligt präglade begreppen som exempelvis deformation eller termisk cykel förklaras av läraren men används inte av eleverna. Om styrdokumentens skrivningar om att elever med viss säkerhet ska kunna använda korrekt fackspråk (Skolverket 2011) ska kunna uppfyllas, krävs istället arbetssätt (hur) som gör att elevernas (vem) språkliga deltagande även innebär att träna på ämnesspråkliga uttryckssätt (vad) (jfr Uljens 1997; Hopman 1997).

Utifrån ett sociosemiotiskt perspektiv (Halliday 1978) kan ämnesspråket ses som ett för kontexten funktionellt och precist sätt att uttrycka ämneskunskaper samtidigt som ämnesspråket ger möjligheter att forma ämneskunskaper. Eftersom språket fungerar som det viktigaste medierande redskapet i kunskapsutveckling (jfr Vygotskij 2001), kan därför en förutsättning för lärande inom skolans ämnesundervisning vara att elever får tillgång till och kontroll över det specialiserade språk genom vilket kunskaper kan bli meningsfulla sammanhang. Ämnesdidaktiskt är situationen under den undersökta lektionen och textsamtalet utmanande. En språkligt komplex text med ett teoretiskt innehåll ska ge specialiserade kunskaper: dels utveckla elevernas fackspråk, dels ett praktiskt lärande. I arbetet med kunskapsinnehållet utgår läraren från ämnesspecifika begrepp ur läroboken och samtalar med eleverna om det med fackspråkliga och vardagliga begrepp och språkformer. Det specialiserade 
språket är då en resurs som kan möjliggöra ämnesspecifikt meningsskapande, vilket kännetecknar mycket av undervisningen i skolan. Ämnesspråket är dock mer än meningsskapande. Det är också:

ett språk som fungerar som inträdesbiljett till den sociala gemenskap som utövare inom ett visst ämnesområde ingår i. Språket spelar alltså, precis som i den tidiga barndomen, en central roll även i den socialiseringsprocess som leder till medlemskap i de nya gemenskaper och roller som kemister, biologer, historiker [svetsare] o.s.v. som skolan ska erbjuda. Följaktligen ingår det i t.ex. historielärarens [och svetslärarens] uppgifter att introducera och systematiskt träna sina elever inte bara i att tänka [och göra] utan också att [läsa] tala och skriva som en historiker [eller svetsare]. (Lindberg \& Kokkinakis 2007: 15).

Vygotskij menade att för att teoretisk förståelse ska utvecklas krävs att teoretiska begrepp får utforskas med stöd i vardagliga begrepp (Vygotskij 1934/2001). En praktik som samtidigt ska bygga ämneskunskaper, praktisk skicklighet och stötta elevers utveckling av ett ämnesspecifikt språk kräver därför språklig rörlighet mellan teoretiska begrepp och mer vardaglig förståelse av dessa. I det undersökta textsamtalet finns en rörlighet mellan språkliga domäner, vilket kan ge eleverna möjlighet att träna på att använda ett språk som är specifikt för svetsare. Läraren säger exempelvis när eleverna säger att det "bågnar" att det kan vara samma sak som när det står "deformation" när de läser teorin, och att man menar samma sak i verkstaden när man säger att "det slår sig". Läraren visar att också läroboken förklarar begreppet deformation med att man också kan säga som det står i boken, att "materialet slår sig" (Henriksson \& Hällman 2009: 97). Ämnesspråk och ämnesförståelse tydliggörs samtidigt i den lexikala kedjan. Läraren knyter orden till olika språkliga domäner: lärobokens språk (teori: "deformation"), vardagsspråk (ni säger: "bågnar") och fackspråk (i verkstaden: "det slår sig”). På så vis medvetandegör läraren eleverna om i vilka kontexter olika språkval är funktionella. Elever som stöttas att utveckla förståelse för innebörden i den typen av olika uttrycksformer och stöttas till rörlighet mellan de olika språkliga domänerna, stöttas samtidigt att utveckla en fördjupad ämnesförståelse (jfr t.ex. Vygotskij 2001; Wertsch 1998) och i det här fallet även till yrkeskunskap.

I den lexikala kedjan i det undersökta samtalet används växelvis olika språkliga uttryck som kan tolkas som tillhörande skilda språkliga domäner. Läraren utgår från ett textcitat, och både lärare och elever använder vardagsspråk då de expanderar detta, alltså bearbetar, utsträcker och förstärker textinnehållet. Tabell 2 ger några exempel ur samtalet på språkliga uttryck presenterade i kronologisk följd. 
Tabell 2. Den lexikala kedjans växelspel mellan språkliga uttrycksformer

\begin{tabular}{|l|l|}
\hline Språkliga uttryck & Språkliga domäner \\
\hline LÄRARE: 'Värmepåverkat material. (HAZ)" & Läroboken \\
\hline ELEV: värme nånting & Vardagligt uttryck \\
\hline LÄRARE: Heat Affected Zone & Läroboken \\
\hline LÄRARE: när ni svetsar tillför ni ju otroligt mycket värme & Vardagligt uttryck \\
\hline LÄRARE: blir värmepåverkat & Läroboken \\
\hline ELEV: krymper & Vardagligt uttryck \\
\hline ELEV: bågnar & Vardagligt uttryck \\
\hline LÄRARE: materialet slår sig & Svetsfackspråk \\
\hline LÄRARE: materialet blir skört & Skolspråklig uttrycksform \\
\hline LÄRARE: hur undviker man... & Skolspråklig uttrycksform \\
\hline \multicolumn{1}{|c|}{..deformationer vid svetsning } & Läroboken \\
\hline $\begin{array}{l}\text { LÄRARE: termisk cykel vid svetsning är ett slags chockvärme- } \\
\text { behandling }\end{array}$ & Läroboken \\
\hline LÄRARE: förvärma & \\
\hline LÄRARE: avglödga & Svetsfackspråk \\
\hline LÄRARE: undvika spänningar och deformationer & Svetsfackspråk \\
\hline
\end{tabular}

De vägar den lexikala kedjan tar i samtalet kan beskrivas som en slags vågrörelse mellan språkliga domäner, ett växelspel mellan lärobokens naturvetenskapligt präglade språk, yrkesspecifikt fackspråk, vardagsspråk och mer formella skolspråkliga former. Ämnesspråket består alltså i den här kontexten av både ett didaktiskt rekontextualiserat svetsfackspråk och ett teoretiskt tekniskt-naturvetenskapligt präglat språk i ett läroboks- och skolspråkligt textsamtalssammanhang (jfr Bernstein 2000). De språkliga domänerna konstruerar tillsammans ett undervisningsspråk som kan vara funktionellt för lärandet i yrkesämnet. Gränsdragningen mellan språkliga domäner är dock komplicerad eftersom språk är kontextbundet och föränderligt och vad som betraktas som formellt och skolspråkligt kan skifta.

Att begrepp som chockvärmebehandling, termisk cykel, förvärma och avglödga framträder i den senare delen av det undersökta samtalet kan tyda på en utveckling av ämnesspråket. Men lärande kräver också insocialisering, och den form av insocialisering som sker är avgörande för vilket lärande som kan ske (Säljö 2010). Eleverna i undersökningen uppvisar ett begränsat ämnesspråkligt deltagande. De deltar genom att lyssna till ämnesspecifika begrepp och kommentera dessa med vardagliga begrepp. Insocialiseringen i ämnesspråket är därmed begränsad och består främst i att de hör läraren använda de ämnesspecifika fackuttrycken (jfr Säljö 2010). Fackspråken rekontextualiseras visserligen alltså didaktiskt (jfr Bernstein 2000), men eleverna fortsätter att använda de vardagliga uttrycken snarare än de ämnesspecifika uttrycken. Eleverna socialiseras därmed in i användandet av ett antal ämnesspråkliga uttryck främst genom lärarens språk snarare än genom aktivt deltagande och tränar inte på att själva använda ämnesspråket. Eleverna socialiseras därmed också in i en praktisk men språkligt mer passiv roll i samtalet.

I den här studien har jag med språkvetenskapliga redskap belyst hur den intertextuella lexikala kedjans utveckling formar innehållet i samtalet, alltså hur orden utforskar, utvecklar och förhandlar ett begrepps meningspotential, samt hur läraren intertextuellt relaterar 
lärobokstext och textsamtal för att stötta förståelse av textinnehållet. Ämnesdidaktiskt har jag i studien försökt belysa hur ämnesspråket är en del av ämneskunskaperna och ämneslärandet. Didaktiska val som utvecklar elevernas ämnesspråkliga förmåga kan därför konstateras vara av vikt $i$ ämnesundervisningen för att stötta elevernas förståelse av ämnesinnehållet. Elever kan också genom att stöttas utveckla ämneslitteracitet, det vill säga förmågan att använda ämnesspråket funktionellt i specifika sammanhang (jfr Shanahan \& Shanahan 2008, 2012). Detta kräver att elever socialiseras in i att bli aktiva deltagare i den yrkesämnesspecifika litteraciteten för att utveckla sätt att självständigt använda ämnestexter och samtala om ämneskunskaper. De didaktiska implikationer som kan dras av studien handlar därför om språkets och läsandets roll i ämneslärande på yrkesprogram, samt de didaktiska val lärare gör i arbetet med text. Om vad i texten läraren väljer att ta upp utgår från de språkliga kompetenser som eleverna behöver i ett modernt yrkesliv kan teoretiskt språk och fackspråk utvecklas (jfr Karlsson 2006). Hur samtalet om detta innehåll byggs upp påverkar det meningsskapande som blir möjligt och vilken möjlighet eleverna ges att träna sig på att "med viss säkerhet" använda "korrekt fackspråk" (jfr Skolverket 2011). Vidare kan en reflektion över vem som deltar i samtalet synliggöra vilka möjligheter eleverna ges att aktivt delta språkligt på en ämnesspråklig nivå där de utvecklar dessa yrkes- och ämnesspråkliga förmågor.

\section{Referenser}

Asplund, Stig-Börje \& Kilbrink, Nina (2018), "Learning How (and How Not) to Weld: Vocational Learning in Technical Vocational Education". Scandinavian Journal of Educational Research, 62(1): 1- 6.

Bachtin, Michail (1986), Speech genres and other late essays. Austin: Univ. of Texas Press.

Bergh Nestlog, Ewa (2019), "Ämnesspråk - en fråga om innehåll, röster och strukturer i ämnestexter". HumaNetten 42: 9-30.

Bernstein, Basil (2000), (Rev.Ed.) Pedagogy, Symbolic Control and Identity. Theory, Research, Critique. Oxford: Rowman \& Littlefield Publishers.

Danielsson, Kristina \& Selander, Staffan (2014), Se texten!: multimodala texter $i$ ämnesdidaktiskt arbete. (1. uppl.) Malmö: Gleerup.

Eggins, Susan (2004), An Introduction to Systemic Functional Linguistics. London: Continuum International Publishing Group.

Gibbons, Pauline (2006), Bridging Discourses in the ESL Classroom. London: Continuum.

Hajer, Maaike \& Meestringa, Theun (2014), Språkinriktad undervisning: en handbok. (2. uppl.) Stockholm: Hallgren \& Fallgren.

Hallesson, Yvonne \& Visén, Pia (2016), 'Intertextual content analysis: an approach for analysing text-related discussions with regard to movability in reading and how text content is handled". International Journal of Research \& Method in Education. 41(2): $142-55$.

Halliday, Michael A. K. \& Hasan, Ruqaiya (1976), Cohesion in English. London: Longman.

Halliday, Michael (1978), Language as a Social Semiotic: The Social Interpretation of Language and Meaning. London: Edward Arnold.

Halliday, Michael \&. Matthiessen, Christian (2004), An Introduction to Functional grammar. London: Arnold.

Halliday, Michael A. K. (2014), Halliday's introduction to functional grammar. (4. ed.) Abingdon, Oxon: Routledge. 
Henriksson, Ivar \& Hällman, Thomas (2009), Bågsvetsning. Fakta om bågsvetsning. Stockholm: Liber.

Holmberg, Per \& Karlsson, Anna-Malin (2006), Grammatik med betydelse: en introduktion till funktionell grammatik. Uppsala: Hallgren \& Fallgren.

Hopmann, Stefan (1997), Wolfgang Klafki och den tyska didaktiken, i Uljens, Michael (red.) 1997. Didaktik: teori, reflektion och praktik. Lund: Studentlitteratur. s. 198-214.

Karlsson, Anna-Malin (2006), En arbetsdag i skriftsamhället: ett etnografiskt perspektiv på skriftanvändning $i$ vanliga yrken. (1. uppl.) Stockholm: Språkrådet.

Lindberg, Viveca (2000), Kärnämnen och karaktärsämnen i samverkan. Utvecklingsarbete inom gymnasieskolans yrkesförberedande program. Stockholm: Skolverket.

Lindberg, Viveca (2003a), "Learning Practices in Vocational Education". Scandinavian Journal of Educational Research. Vol. 47(2): 157-179.

Lindberg, Viveca (2003b), "Vocational knowing and the content in vocational education". International Journal of Training Research, 1(2): 40-61.

Lindberg, Inger \& Kokkinakis Johansson, Sofie (2007), OrdiL - en korpusbaserad kartläggning av ordförrådet i läromedel för grundskolans senare år. Göteborg: Rosa. Institutionen för svenska språket.

Linell, Per (1998), Interaktionen i samtal - en teoretisk bakgrund, i: Forstorp, Per-Anders \& Linell, Per (red.) Samtal pågår dialogiska perspektiv på svenska mediedebatter. Enskede: TPB. s. 9-48.

Martin, James M. \& Rose, David ( 2007), Working with discourse: meaning beyond the clause. (2. [rev.] ed.) London: Continuum.

Olvegård, Lotta (2014), Herravälde: är det bara killar eller?: andraspråksläsare möter lärobokstexter $i$ historia för gymnasieskolan. Diss. Göteborg : Göteborgs universitet, 2014. Göteborg.

Schleppegrell, Mary J. (2004), The language of schooling: a functional linguistics perspective. Mahwah, NJ: Lawrence Erlbaum.

Shanahan Timothy \& Shanahan Cynthia (2008), "Teaching disciplinary literacy to adolescents". Harvard Educational Review, 78(1): 40-59.

Shanahan Timothy \& Shanahan Cynthia (2012), "What Is Disciplinary Literacy and Why Does It Matter?" Topics in Language Disorders. 32(1): 7-18.

Skolverket (2011), Ämnesplan Sammanfogningsteknik. Industritekniska programmet. https://www.skolverket.se/laroplaner-amnen-och-kurser/gymnasieutbildning /gymnasieskola/sok-amnen-kurser-och-program/subject.htm?subjectCode=SAA \&courseCode=SAASVT0\&lang=sv\&tos=gy\#anchor_SAASVT0 [hämtad 2017.05.31].

Säljö, Roger (2010), Lärande $i$ praktiken: ett sociokulturellt perspektiv. (2. uppl.) Stockholm: Norstedts.

Wertsch, James V. (1998), Mind as action. New York: Oxford University Press.

Uljens, Michael (1997), School didactics and learning: a school didactic model framing an analysis of pedagogical implications of learning theory. Hove: Psychology Press.

Unsworth, Len (2001), Teaching multiliteracies across the curriculum. Changing contexts of text and image in the classroom practice. Buckingham Philadelphia: Open University Press.

Visén, Pia (2015), Att samtala om texter: från träteknik och svetsteori till antikens myter. Textsamtalets möjligheter som närmaste zon för läsutveckling $i$ en klass på gymnasiets industritekniska program. Diss. Stockholm: Stockholm University.

Vygotskij, Lev Semjonovitj (2001), Tänkande och språk. Göteborg: Daidalos. 